\title{
Valuing workers' housing as heritage of post-liberation China: measuring public perception of Caoyang New Village, Shanghai
}

\author{
Y.-W. Wang ${ }^{1}$, X. Zhang \& L. Sun ${ }^{2}$ \\ ${ }^{1}$ Department of Urban Planning and Design, \\ $X i$ 'an Jiaotong-Liverpool University, China \\ ${ }^{2}$ Department of Geography and Planning, University of Liverpool, UK
}

\begin{abstract}
This paper is concerned with the implications of according heritage status to Caoyang Village One - Communist China's first social housing project. Completed in 1952, the housing estate has been portrayed as a 'model' modern housing for the working class. As an embodiment of the socialist ideal of postliberation China, Village One was designated by the Shanghai Municipal Government as Heritage Architecture in 2005 and has been statutorily protected since then. This research is set out to measure the public perception of post-war housing heritage. The research adopts the SUIT Methodology, which is acknowledged by the ICOMOS International Committee for Historic Towns and Villages (CIVVIH) as an exemplary methodology for involving the public in heritage significance evaluation. One objective of the research is to understand how various stakeholders within and outside the Caoyang New Village perceive the heritage value of Village One; whether the designation of Village One consequently makes people more positively appreciate it; and how a wider public perceive this post-war housing heritage, a type of buildings that is strange to the country's heritage inventory. The other objective is to assess how the public perceive proposed changes to the physical structures of heritage buildings and to which extent physical alternation to the heritage structures is considered acceptable. Research results can not only inform heritage authorities with evidence-based research and yield new insight into post-war housing conservation, but also contribute to the body of knowledge concerned with the issue of public participation in heritage field.
\end{abstract}

Keywords: heritage value assessment, public involvement, housing heritage. 


\section{Introduction}

Over the past two decades or so, post-war public housing has gradually received recognition for its significant role in the mid- $20^{\text {th }}$ century against the backdrop of post-war reconstruction. Since the early 1990s, more and more economically advanced countries have begun to validate post-war housing estates as cultural heritage. In China, such trend began in the mid-2000s. Well known examples include Caoyang New Village in Shanghai, Qingshan Red Houses in Wuhan built in the 1950s, and several Commune Apartment Blocks in Beijing built in the $1960 \mathrm{~s}$, all of which were accorded with heritage status by the local authority in the last decade. In these cases, the decision on listing is essentially top-down, despite the local government's claims of public involvement in publicity materials. These estates were listed because "worker's housing" is seen by experts as highly symbiotic of the Communist China on political and ideological grounds. However, arguably, the significance of housing heritage should be, at least in part, derived from social or communal values attached and appreciated by a wider range of stakeholders, ranging from local residents to the general public. The question needs to be asked is whether people thereof share the same view of experts working at/for the local heritage authority and see these housing estates as cultural "assets" of the locality - or not at all.

There has been a growing interest in extending the domain of public involvement in heritage protection, as public perceptions and attitudes towards heritage, along with their significance and values attached to historical places, have received sustained attention from the heritage sector at local, national and international levels [1-4]. Among all the different types of heritage structures, residential buildings arguably mandate a greater extent of public involvement than other building types in heritage identification, conservation and management $[5,6]$. However, there has been an inevitable discrepancy between experts and the general public in the ways that the significance of a place is appreciated. If heritage is "our" common inheritance, how can we ensure that the ways experts value a historical place represent the view of a heterogeneous society? If the public perception of heritage value could be measured, findings from the public perception survey can either support experts to make informed decisions or endorse their judgments on heritage designation. Similarly, with the growing tendency in heritage sector to exploit the economic potential and market value of the historic environments, contemporary design intervention has been increasingly considered an indispensable part in any conservation projects. In place of preserving old buildings in aspic, the issue of how to blend the new with the old has come to the fore in the present-day heritage management $[7,8]$. Consequently, the increasing degree of destruction, or the decreased level of retention of original structures, has proven highly contentious.

The main objectives of this research, therefore, are twofold: to understand the public perception of post-war housing as heritage and, also, to which extent physical alternation to its original structures is considered acceptable in the sense that such changes will not diminish the authenticity and integrity of statutorily protected structures. 


\section{Whose housing heritage?}

Housing designation and conservation is arguably the most controversial subject in heritage protection, due to the vast number, ubiquity and repetitiveness of the structures [9]. However, controversy provoked by listing and conserving postwar social housing is even fiercer, owing to its long-standing dubious reputation for technical malfunction and social notoriety. In addition, another controversial issue about post-war housing heritage that is often debated yet unlikely to be resolved is the question of for whom we conserve housing estates. Perhaps the most fundamental question to ask is: whether the local communities should have any role to play in making a decision on listing? And if so, how?

\subsection{The inferiority of social values of housing heritage}

One major criticism that the heritage legislation system often receives is its perceived elitist value judgment, since the whole rationale behind the listing process and the ways that decisions are made are invariably based on architectural or historical criteria. In contrast to the top-down, elitist approach, which tends to attach importance to fundamental (aesthetic or design) values of a housing estate, is the bottom-up approach of estate residents, who often embody the idea of heritage as social action and highlight the communal (social) values of the estate they live. Heritage legislation for listing has been developed and structured in association with architectural history, rather than social attributes. As such, social values have never been the sole justification for listing. In fact, sense of place and community is more like an auxiliary value. The hierarchical structure of value classification proposed by English Heritage, also suggests the inferiority of intangible values to tangible ones. Heritage values embedded in a historic place may range from the high-level evidential values, through historical and aesthetic, to the low-level 'communal values which derive from people's identification with the place' [10]. While the communal/social value can greatly enhance the cultural significance of a place that holds other 'core' heritage value, the current legislation does not incline towards local sentiments as the sole justification for listing. In addition, the ways in which current conservation practices form judgments as to the best course of action in conserving post-war housing estates often places a greater emphasis on material heritage but shows relatively limited concern on social regeneration. The inferiority of social values appears evident.

Despite its limited importance, social value admittedly has broadened our ideas about what heritage is and about whom the national heritage reflects. The controversy over post-war housing listing underlines the fact that the conventional heritage canons have been long associated with elite interests but rarely with the concerns of the lower stratum of society. Social values, therefore, are important for adjusting and redefining our parameters in heritage designation and subsequent conservation. However, yet again, the difficulty lies in whether social values can be measured, quantified and then converted into an "objective" assessment system to evaluate their heritage significance. 


\subsection{Quantifying perceived values?}

The prevailing philosophy today in the heritage field is that the ultimate goal of conservation is not merely about preserving tangible substances but, more importantly, to sustain the intangible values that have been attached to a property - the idea of "cultural heritage" as a social construction $[11,12]$. The so-called 'heritage values' in part derive from the object itself but for the most part are ascribed by the subjects, and they are appreciated by people in many different ways with varying degrees. As such, although an evaluation framework like value classification is created to serve as a mechanism to rationalise or justify decision-making, it has marginal impact on the legislative system of heritage protection. This is also the reason why such assessment mechanisms tend to elaborate on the fundamental values that are intrinsic to historical structures, but they may tend to exclude the incidental values that are generated as a result of cultural practice, especially the commodification of cultural heritage [13].

Extensive research has been carried out on public attitudes toward the historic environment $[2,14]$. However, these studies tend to focus on the relationship between invested governmental inputs and produced financial outputs in heritage management. While public bodies has placed much of their focus on how institutional capacity of public organisations could better respond to the public value, alternative concepts of public value have also been developed to address the role of public in assigning values of heritage [15-17]. Addressing a more fundamental level, Tweed et al. [16] developed a survey method to assess public perceptions and attitudes to urban historical areas. Acknowledging the gap in studies on the interaction between human being and the environment, a team of researchers of the SUIT project ('Sustainable Development of Urban Historical Areas through an Active Integration within Towns) designed an in-situ survey tool to assist local authorities in assessing the value of built heritage.

The SUIT survey methodology has been acknowledged by the ICOMOS CIVVIH since 2006 as an exemplary methodology for involving the public in heritage significance evaluation [18]. Based on questionnaire surveys, this quantitative tool is designed to measure perceived heritage values in relation to a historic place and proposed changes to the place. The methodology has been applied to several European urban cultural settings and "showed that it is possible to provide quantitative data for a qualitative subject area - 'perceived value"" [19]. Conclusions are drawn in term of the range of indicators to quantify the perceived equalities of a historical area, and it is stated that the survey technique "could be adapted to different cultural and urban settings" [17].

What should be stressed is that the intended focus of the SUIT survey are historical structures and places that may not be considered to be worthy of designation yet form part of the essential character of the locality. While the methodology was set to campaign for the retention, or inclusion of humble heritage within the assessment procedure of defining the scope of Environmental Impact Assessment, it also reflects a rising interest in considering minor heritage that falls outside the realm of statutory protection. As stated previously, this research intends to develop a better understanding of public perception of post- 
war social housing - one of the most controversial categories of heritage. This pilot study adapts the SUIT survey method to measure how the public values housing heritage in the Chinese cultural context.

\section{Caoyang New Village}

Caoyang Village One, (hereafter VLG \#1) is the very first social housing estate built by the Communist government of China. As part of the government's propaganda campaign, this housing estate was built to provide decent homes for "model workers". It has been portrayed as a 'model' modern housing for the working class, who were the vanguard of the political fight for liberation, and VLG \#1 is an embodiment of the socialist ideal of post-liberated China.

Completed in 1952, VLG \#1 covers an area of 13.3 hectares, consisting of 48 two-storey buildings (later extended to three storeys) and housing 1,002 families (Figure 1). Following that, another eight residential quarters were built adjacent to it in the following two decades. The nine-phase construction until 1977 - from VLG \#1 to \#9 - which covers an area of 180 hectares and houses 100,000 people and 32,000 households, is now known as Caoyang New Village (CYNV). CYNV has a close link with Shanghai's short industrial history, from the funding of People's Republic of China in 1949 to the economic reform in 1978. The 30year industrial history is a period faintly addressed in historical accounts and

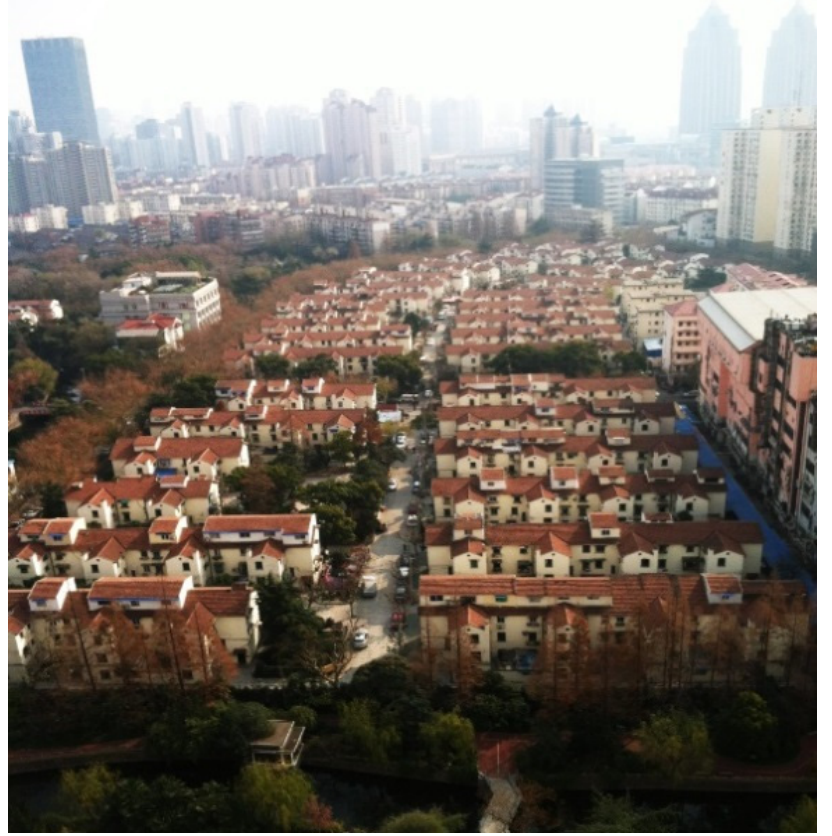

Figure 1: Caoyang VLG \#1 stands in sharp contrast to its surroundings. 
film retrospectives, and Shanghai's industrial past in the post-war years has been habitually ignored or forgotten. Nonetheless, the listing of VLG \#1 as 'Heritage Architecture' in 2005, perhaps, signals a turn.

As a purpose-built model village for model workers, VLG \#1 had served as a showcase for foreign visitors as well as people in the country to see the excellent living conditions that China's working class could enjoy - at least for those who were considered the best employers in their "working units", though not for everyone. Modelled after the American planning idea "neighbourhood unit" proposed in the 1920s, VLG \#1 was built of a high standard especially in term of its community amenities and public open spaces. The layout of this low-rise and low-density residential quarter featured a maze of winding streets and footpaths that corresponded organically to the topographic features of the site. Such American suburban housing development model had never been reproduced elsewhere in Shanghai since then. Instead, the dominant housing type had been characterised by rows and rows of large-scale and standardised Soviet-style apartment blocks until the 1970s. The VLG \#1 is, therefore, regarded as a unique example in the history of Shanghai's housing development. Whereas VLG \#1 has received official recognition from the authority, how the public perceives this new category of heritage remains unknown. This research is set to explore whether, and to which extent that, people could perceive qualities and values of this 1950 s social housing and proposed changes to its physical attributes.

\subsection{Survey design and results}

The research adopted the SUIT methodology and carried out two face-to-face questionnaire surveys within the CYNV to measure personal experience on the actual site and direct response to the real space from various groups of stakeholders. In other words, perceptions were recorded and captured at the real site and in-situ rather than remotely as a desk-based or online survey [19].

The distinction between the two surveys is to understand different perception between "external" and "internal" stakeholders, i.e. the general public and CYNV residents. The targeted respondents of the first survey were the general public, yet the CYNV residents were not necessarily excluded as they also formed part of the public view. The survey locations were evenly distributed across the entire CYNV and major public spaces in close proximity. It was conducted in the autumn of 2012 with the completion of 189 questionnaires. The second survey targeted at the residents of VLG \#1 and \#7, and was conducted in the autumn of 2013 with 117 questionnaires completed by our fieldworkers interviewing residents at the doorstep or in their homes. For the comparative purpose, VLG \#7 was included in the survey so to understand how people may perceive the quality and proposed change to the designated VLG \#1 and the nondesignated VLG \#7 differently. While VLG \#1 is under statutory protection and any physical alteration to the buildings is, in principle, prohibited, VLG \#7 is not statutorily protected so contemporary intervention in its original structures is comparatively acceptable. The following sub-sections detail some of the main findings from the surveys. 


\subsubsection{The perceived quality of place}

To understand the quality of a place as perceived by the general public and the local residents, respondents were presented with the photos of VLG \#1 and \#7 (Figures 2(a) and 3(a)) and asked "Do you like this view?" by rating it on a scale from 1 to 5. The survey results shown in Table 1 indicates that, while the general public's perception of the VLG \#1 and \#7 were almost the same, local residents perceived VLG \#1 more positively and of better quality than VLG \#7.

When being asked "Can you explain the reason why?" by ticking a given list of qualities of the place, the response from both surveys were similar. Both VLG $\# 1$ and \#7 were rated positively for their public open space, tree-lined streets and building design/function, yet perceived negatively for the building design and function. Rather few respondents, even for local residents, related qualities of the place to "personal memories/experiences" and "social life links". It appears that the perceived quality was mainly about the built environment, but intangible values were rarely perceived as quality.

Table 1: The perceived quality of the place.

\begin{tabular}{|l|c|c|c|c|c|c|}
\hline \multirow{2}{*}{ Questions } & \multicolumn{3}{|c|}{$\begin{array}{c}\text { Survey 1. 189 samples } \\
\text { the general public }\end{array}$} & \multicolumn{3}{c|}{$\begin{array}{c}\text { Survey 2. 117 samples } \\
\text { VLG \#1 and \#7 residents }\end{array}$} \\
\cline { 2 - 7 } & dislike & neutral & like & dislike & neutral & like \\
\hline $\begin{array}{l}\text { Do you like this view? } \\
\text { of VLG \#1 }\end{array}$ & $24 \%$ & $\mathbf{5 0 \%}$ & $26 \%$ & $21 \%$ & $\mathbf{4 0 \%}$ & $\mathbf{3 9 \%}$ \\
\hline $\begin{array}{l}\text { Do you like this view? } \\
\text { of VLG \#7 }\end{array}$ & $27 \%$ & $\mathbf{5 3 \%}$ & $20 \%$ & $\mathbf{5 5 \%}$ & $\mathbf{2 9 \%}$ & $16 \%$ \\
\hline
\end{tabular}

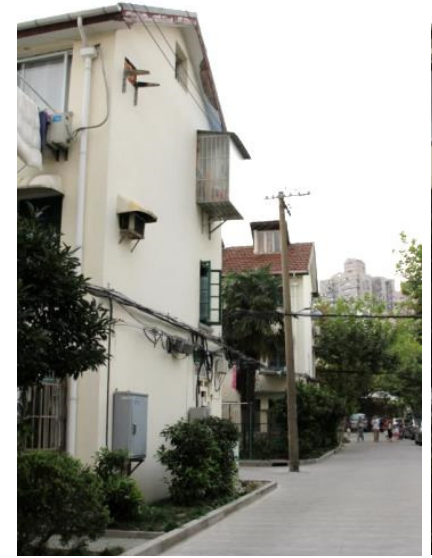

(a)

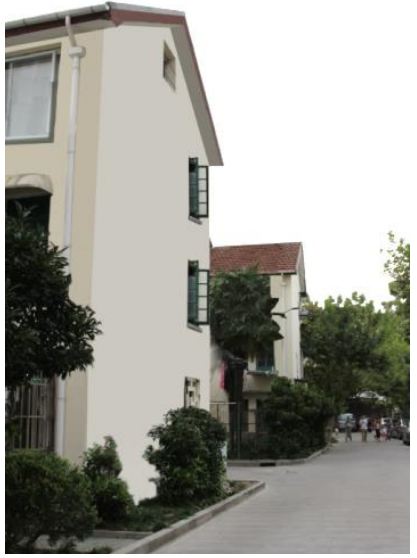

(b)

Figure 2: The original photo of VLG \#1 (a) and the altered one (b) with the removal of cables, window ledge, and the tall building in the view. 
When being asked to name the three best/worst things about CYNV, there is no distinct diffidence between the two surveys. The features of the place valued positively by the respondents are outdoor environment, location, transport connection and community facilities; but living standard and building conditions was perceived as inadequate. The worst features perceived were all related to building conditions, to which local authorities in their future consideration for conservation should devote attention. The valued features of place were mostly related to tangible attributes, and intangible values often seem to be neglected.

\subsubsection{Awareness and attitudes toward change to the place}

Measuring public awareness and attitudes towards proposed intervention to a historical place was one of the main aims of the research and formed a major section in the questionnaire survey. Being presented with four altered photos of VLG \#1 and \#7 (Figures 2 to 5), respondents were asked whether they noticed

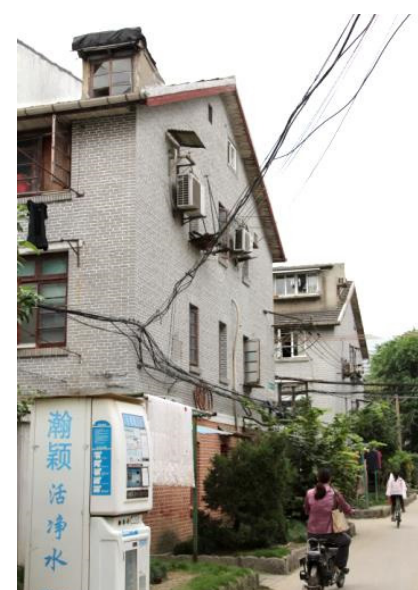

(a)

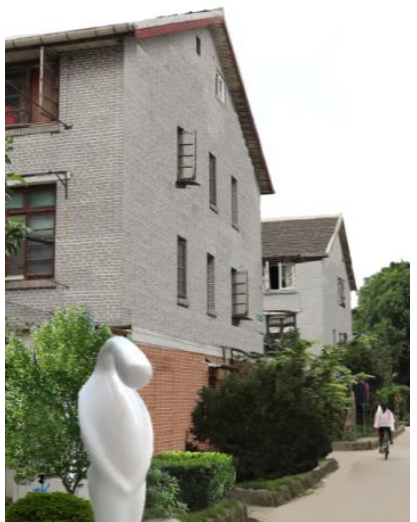

(b)

Figure 3: The original photo of VLG \#7 (a) and the altered one (b), with the installation of public art and the removal of untidy mess.

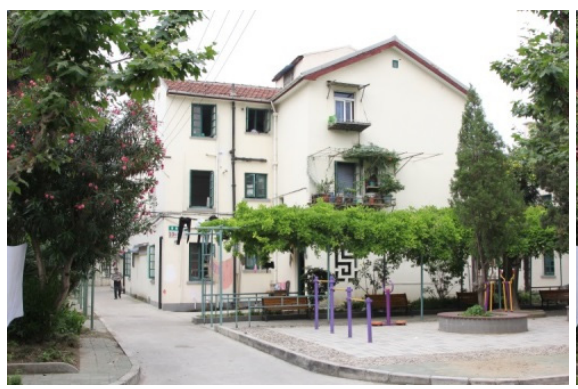

(a)

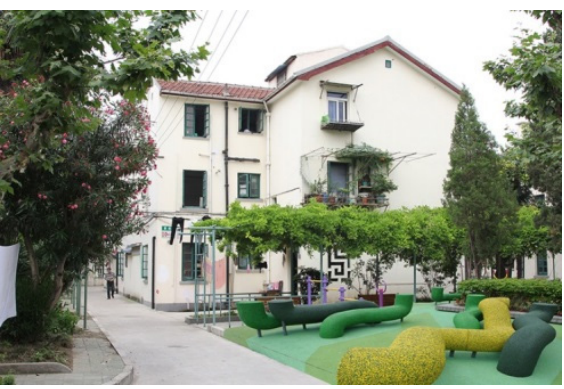

(b)

Figure 4: VLG \#1 (a) and the altered photo (b) with new street furniture. 


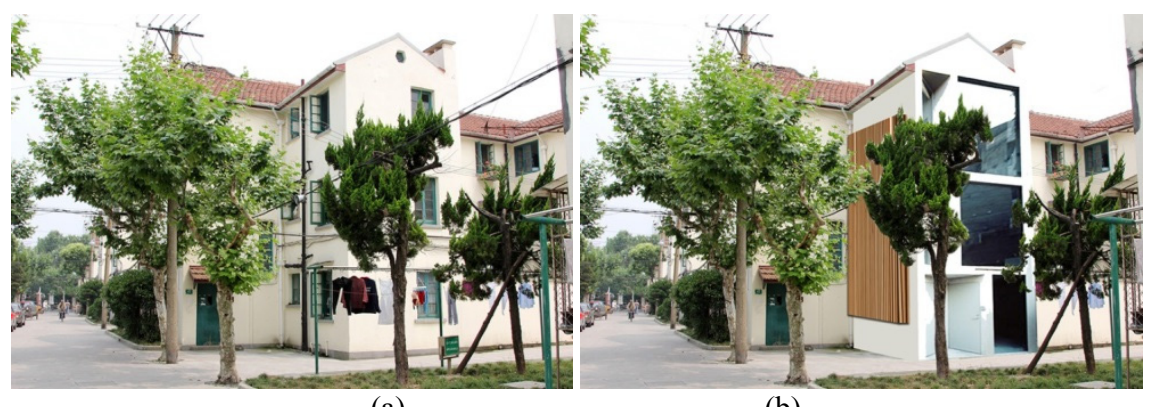

(a)

(b)

Figure 5: VLG \#1 (a) and the altered photo (b) with a considerable alteration to building elevations.

anything different about the photos. After the interviewers indicated the alterations made to the photos, respondents then were asked how they would feel if these changes were actually carried out.

Table 2 details all the responses in percentage. Briefly summarising the findings, the proposed alterations to the place, in general, were perceived by respondents, and residents of VLG \#1 and \#7 could easily notice changes than the general public. These alterations - from the removal of untidy mess, installation of street furniture, to alteration to the façade of listed VLG \#1 - were clearly favoured by the general public. Local residents, conversely, perceived these alterations in a different way, mainly from their personal interest.

Table 2: $\quad$ Awareness and attitudes toward change.

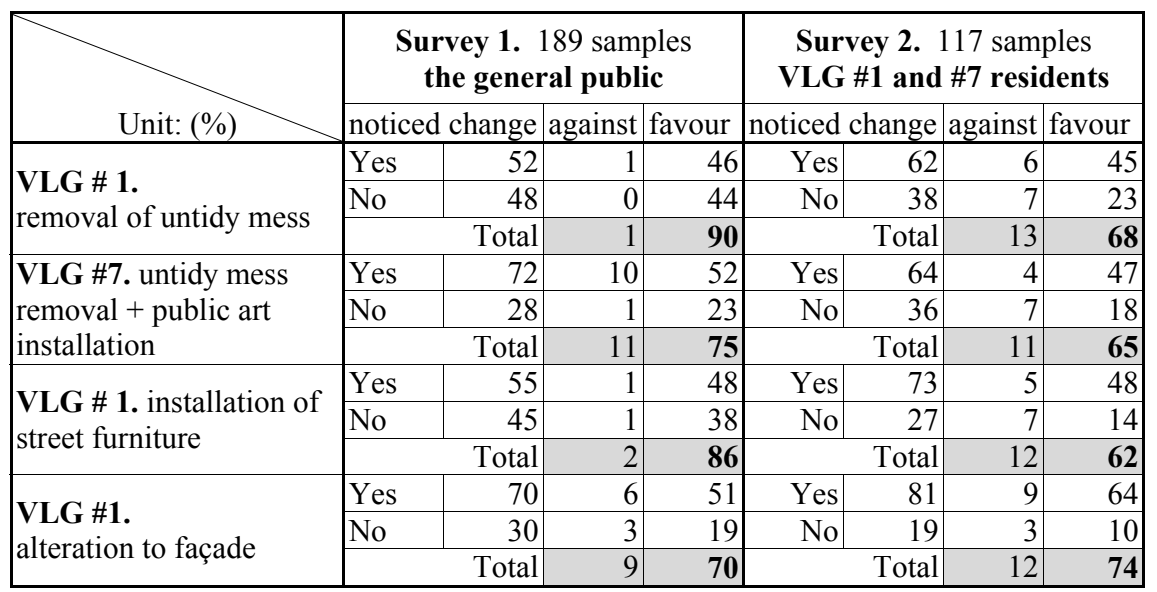

Due to the private ownership, local residents stood against proposed changes that may conflict with their day-to-day needs. For instance, the altered picture of Figures 2 and 3 suggested carrying out restoration work to VLG \#1 and \#7. While no significant difference between the two implies heritage status makes no 
much difference, some were against the change because they were afraid that their illegal structures on the ground/roof floor would be removed.

Intriguingly perhaps, Figure 5 exhibiting an alteration made right upon the physical structures of listed VLG \#1 was positively received. The relatively high degree of acceptance of such change may partially stem from the fact that VLG $\# 1$ is a post-war structure, whose age and rarity is not highly valued as to enjoy a higher degree of flexibility for change. The other plausible explanation would be, as noted in the previous section, many residents were discontent with living conditions of their flats and many buildings are in need of repair. Alteration to the building exterior somewhat implies the renovation of the interior and the upgrade of building services and, on this account, it is not surprising to see why physical alteration to heritage structures was positively perceived.

Finally, the survey ended with asking respondents "Do you believe that, if any changes in this area were going to be made that your opinion would be taken into account?" Surprisingly, the results (Table 3 ) were beyond our expectation. While similar studies conducted in European cities show very low confidence and distrust towards participation [17, 19], the survey with the general public and local residents respectively has $42 \%$ and $55 \%$ of respondents who believed that their opinions would be taken into account in the future. This rate of confidence is remarkably high, considered that public engagement rarely included in the planning process in China - without regard to new development or conservation projects. In addition, during the survey, many residents of VLG \#1 appeared to have hostile attitudes toward any form of survey. The residents were annoyed by the repeated disturbance of questionnaire and interview surveys conducted by local planning authority and research institutes, yet they have not seen any changes consequently. Whereas this may suggest a loss of public trust in local authority and public participation, the high confidence rate of CYNV could not be accounted for based on the findings from this survey.

Table 3: Confidence in the further consideration of one's pinion.

\begin{tabular}{|c|c|c|c|c|c|c|}
\hline & \multicolumn{6}{|c|}{ Survey 1.189 samples of the general public } \\
\hline & $\begin{array}{l}\text { strongly } \\
\text { believe }\end{array}$ & believe & disbelieve & $\begin{array}{l}\text { strongly } \\
\text { disbelieve }\end{array}$ & don't care & not sure \\
\hline \multirow{2}{*}{$\%$} & 3 & 39 & 10 & 41 & 3 & 4 \\
\hline & \multicolumn{2}{|c|}{42} & \multicolumn{2}{|c|}{51} & & \\
\hline
\end{tabular}

\begin{tabular}{|c|c|c|c|}
\hline \multirow{3}{*}{} & \multicolumn{3}{|c|}{ Survey 2. 117 samples of VLG \#1 and \#7 residents } \\
\cline { 2 - 4 } & believe & disbelieve & others \\
\hline$\%$ & $\mathbf{5 5}$ & $\mathbf{4 5}$ & 0 \\
\hline
\end{tabular}

\subsubsection{Perceived heritage values (Survey 2 only)}

An additional set of questions were added to the questionnaire of Survey 2 so to investigate how local residents perceived the designation of VLG \#1 as Heritage Architecture. As shown in Table 4, while $72 \%$ of respondents were not surprised 
by the listing, the view on whether it deserves a heritage status shows a nearly half-half split. When being asked the reasons why it should be listed, all the respondents acknowledged its historical values, though some felt doubtful due to its poor condition of building and living standard. This suggests local residents somewhat share the view of experts and were not reluctant to accept VLG\#1 became a heritage asset, even though social housing has never been included in Shanghai's heritage inventory. Nonetheless, none of them mentioned social values and intangible aspects of the place.

Table 4: Heritage values perceived by local residents.

\begin{tabular}{|l|c|c|c|}
\hline \multicolumn{4}{|c|}{ Survey 2. 117 samples VLG \#1 and \#7 residents } \\
\hline Questions & Yes & No & Unsure \\
\hline Surprised when heard VLG \#1 being listed? & $27 \%$ & $\mathbf{7 3 \%}$ & -- \\
\hline VLG \#1 deserves its heritage title? & $\mathbf{5 4 \%}$ & $46 \%$ & -- \\
\hline $\begin{array}{l}\text { Reasons why VLG \#1 should be listed. } \\
\text { (frequency count) }\end{array}$ & $\begin{array}{l}\text { historical values (123); } \\
\text { good environment (16); } \\
\text { good building/appearance (16) }\end{array}$ \\
\hline $\begin{array}{l}\text { Reasons why VLG \#1 shouldn't be } \\
\text { listed.(frequency count) }\end{array}$ & $\begin{array}{l}\text { poor living condition (36); } \\
\text { poor appearance (21); } \\
\text { poor building quality (11). }\end{array}$ \\
\hline
\end{tabular}

\subsection{Discussion}

As a result of the international collaboration among EU funded projects, the SUIT methodology have been adapted to different cultural and urban settings, but its application to date appears to be confined to historic sites in Europe. Neither has it been field tested in a non-European context nor it has been applied to measure the public perception of the 20th-century modern heritage. Whereas the employment of the SUIT survey methodology in this research has further validated its sensitivity to different cultural contexts, the survey undertaken by this research has also tested its practicality for capturing the public perception of post-war housing heritage. The methodology is a useful tool for obtaining empirical quantitative data regarding public perception and could be used as an approach for a bottom-up heritage designation and conservation. However, to which extent it can serve as a practical tool to quantify the intangible value remains questionable.

\section{Conclusion}

To date, Caoyang Village One is the only post-1949 social housing that receives heritage status. Despite its unassuming appearance, it is arguably an iconic housing project in the history of the People's Republic of China. It receives heritage status because it represents the pragmatic socialism of Post-liberated China. In a sense, this group of residential buildings is considered "monumental" 
and by no means "ordinary". It is still yet to seen whether the designation of VLG \#1 is an exceptional case or, conversely, results in more designations. While the rise of interest in industrial heritage in China has led to widespread reflection about the trajectory of the country's industrialisation, it can be optimistically inferred that statutory protection will further extend to other housing estates, as the conservation movement tends to adjust its parameters to include a new type of buildings. This research began with a preposition that local communities should be involved in the process of housing designation and conservation, but how to do it is the main challenge. The SUIT survey methods were employed as a tool to serve the purpose, but the survey results have suggested its limited capacity to capture or quantify intangible values. Perhaps the accountability and reliability of such quantitative survey methods remain to be subjected to more critical scrutiny.

\section{References}

[1] Avrami, E., R. Mason, and M.d.1. Torre, Values and Heritage Conservation: Research Report. 2000, The Getty Conservation Institute: Los Angeles.

[2] MORI, Making Heritage Count? 2003, English Heritage, DCMS and HLF: London.

[3] Dupagne, A., et al., SUIT: sustainable development of urban historical areas through integration within towns. European Commission Research Report No. 16 2004, Luxembourg: European Communities.

[4] Council of Europe, CETS No.199. Council of Europe Framework Convention on the Value of Cultural Heritage for Society. 2005, Council of Europe: Faro.

[5] Larkham, P.J., J. Pendlebury, and T. Townshend, Public Involvement in Residential Conservation Planning: Values, Attitudes and Future Directions, in Planning in the UK: Agendas for the new millennium, Y. Rydin and A. Thornley, Editors, Ashgate: Aldershot. pp. 237-256, 2002.

[6] Townshend, T. and J. Pendlebury, Public participation in the conservation of historic areas: Case-studies from north-east England. Journal of Urban Design, 4(3): pp. 313-331, 1999.

[7] English Heritage, Constructive Conservation in Practice. 2008, English Heritage: London.

[8] Schittich, C. and S. Breitling, Building in existing fabric: refurbishment, extensions, new design. 2003, Basel: Birkhũser. 176 p. ill. (chiefly col.), plans; $30 \mathrm{~cm}$.

[9] Smith, P. Post-war listed buildings. Context, 2000.

[10] English Heritage, Conservation Principles, Policy and Guidance: for the Sustainable Management of the Historic Environment. 2008, English Heritage: London.

[11] Ashworth, G.J., Conservation as preservation or as heritage: two paradigms and two answers. Built Environment, 23(2): pp. 92-192, 1997.

[12] Smith, L., Uses of heritage. 2006, Abingdon: Routledge. 
[13] Pendlebury, J.R., Conservation in the age of consensus. 2008, London: Routledge.

[14] Accenture and National Trust, Demonstrating the Public Value of Heritage. 2006, Accenture and the National Trust: London.

[15] Commission for Architecture \& the Built Environment, Physical capital: How great places boost public value. 2005, Commission for Architecture \& the Built Environment: London.

[16] Tweed, C., M. Sutherland, and J. Teller, Identifying the relations between historical areas and perceived values: introduction to issues and indicators. SUIT project report on Task 2.1a. 2002.

[17] Sutherland, M., C. Tweed, and J. Teller, Identifying the relations between historical areas and perceived values: Field-tested methodology to measure perceived quality of historical area. SUIT Project Report on Task 2.1b. 2002.

[18] European Association of Historic Towns and Regions, Investing in Heritage - A Guide to Successful Urban Regeneration. 2007: Norwich.

[19] Tweed, C. and M. Sutherland, Built cultural heritage and sustainable urban development. Landscape and Urban Planning, 83(1): pp. 62-69, 2007. 